\title{
The CIEL Franco-Belgian Database (Collectif interuniversitaire d'étude du littéraire)
}

La base de données francophone belge du CIEL (Collectif interuniversitaire d'étude du littéraire)

La base de datos francófona belga de CIEL (Colectivo interuniversitario de estudio de lo literario)

\section{Björn-Olav Dozo}

Translator. Michelle Arriss, Delaina Haslam and Séverine Sofio

\section{(2) OpenEdition}

\section{Journals}

Electronic version

URL: http://journals.openedition.org/bssg/227

DOI: $10.4000 /$ bssg. 227

ISSN: 2490-9424

\section{Publisher}

Presses universitaires de Vincennes

\section{Electronic reference}

Björn-Olav Dozo, "The CIEL Franco-Belgian Database (Collectif interuniversitaire d'étude du littéraire)", Biens Symboliques / Symbolic Goods [Online], 2 | 2018, Online since 12 April 2018, connection on 04 March 2021. URL: http://journals.openedition.org/bssg/227 ; DOI: https://doi.org/10.4000/bssg.227 


\title{
La base de données francophone belge du CIEL (Collectif interuniversitaire d'étude du littéraire) \\ The CIEL Franco-Belgian Database (Collectif interuniversitaire d'étude du littéraire)
}

\author{
Björn-Olav Dozo
}

traduction | translation

Michelle Arriss | Delaina Haslam | Séverine Sofio

\begin{abstract}
Comment est né le projet de base de données ?
La base de données du Collectif interuniversitaire d'étude du littéraire (CIEL) est le fruit d'une collaboration entre I'Université libre de Bruxelles et l'Université de Liège : cette initiative de recherche collective a été dirigée par Paul Aron et Jean-Marie Klinkenberg et coordonnée par Benoît Denis. Ce projet fut financé par la Communauté française de Belgique de 2002 à 2007 à Liège et à Bruxelles, puis de 2008 à 2013 à Bruxelles. Plusieurs thèses ont été réalisées en son sein ${ }^{1}$.
\end{abstract}

La base de données a été réalisée par le Centre informatique de philosophie et lettres (CIPL), alors sous la direction de Gérald

1 Sur la genèse du projet CIEL, se reporter à l'article de Paul Aron, Benoît Denis et Jean-Marie Klinkenberg (2006).

\section{How did the database project begin?}

The Collectif interuniversitaire d'étude du littéraire (CIEL) database is the result of a collective research initiative: a collaboration between the Université libre of Brussels and the Université de Liège; it was directed by Paul Aron and Jean-Marie Klinkenberg and coordinated by Benoît Denis. The project was financed by the Communauté française de Belgique from 2002 to 2007 in Liège and Brussels, and then from 2008 to 2013 in Brussels. Several theses have resulted from it. ${ }^{1}$

The database was developed by the Centre informatique de philosophie et lettres (CIPL), at that time under the management

1 On the genesis of the CIEL project, see the article by Paul Aron, Benoît Denis, and Jean-Marie Klinkenberg (2006). 
Purnelle 2 . Le CIPL, créé en 1983 à l'Université de Liège, est une Unité décentralisée d'informatique (UDI), qui correspond actuellement à un centre de recherche et de développement en humanités numériques. Son objectif général est de promouvoir et coordonner l'utilisation de l'informatique au sein de la faculté de philosophie et lettres de l'Université de Liège et d'assurer l'accompagnement et les développements des projets informatiques pour la recherche et

l'enseignement.

Luc Desert, informaticien au CIPL, a développé la base du CIEL de 2002 à 2005. Formé par ce dernier, Björn-Olav Dozo a d'une part assuré (avec Daphné de Marneffe) l'encadrement des étudiants chargés de compléter la base de données et d'autre part exploité les données de manière sérielle.

\section{Comment les corpus ont-ils été délimités ?}

La base a deux objectifs principaux : I'un patrimonial, l'autre plus " expérimental ». Le premier découle du constat que l'histoire de la littérature belge de langue française s'est écrite au gré d'initiatives éparses, provoquant de grandes disparités dans la documentation actuellement disponible. La constitution de la base de données vise d'abord à compiler les informations déjà existantes, à les corriger s'il y a lieu, puis à les mettre à jour. Le support informatique est le format idéal pour ce type de données en incessant devenir. Le deuxième objectif vise à traiter statistiquement cette masse de données.

2 Actuellement président du CIPL, et enseignant-chercheur chargé des cours de poésie francophone de Belgique. La direction du CIPL est assurée par Björn-Olav Dozo depuis septembre 2016. of Gérald Purnelle. ${ }^{2}$ The CIPL, created in 1983 at the Université de Liège, is a Unité décentralisée d'informatique (UDI), which currently corresponds to a research and development centre for digital humanities. Its general objective is to promote and coordinate the use of computer science within the Faculté de philosophie et lettres of the Universite de Liège and to ensure the support and development of data processing projects for research and teaching.

Luc Desert, a computer scientist at the CIPL, developed the CIEL database from 2002 to 2005. A trainee of Desert, BjörnOlav Dozo ensured (with Daphné de Marneffe) the supervision of students assigned to complete the database, but also serially ran the data.

\section{How was the corpus defined?}

The database has two primary goals: the first one is patrimonial, the second is more "experimental." The first ensues from the acknowledgement that Belgian Francophone literature came about as a result of diverse initiatives thus causing major disparities in the documentation that is currently available. The database conception firstly aims to compile the already existing data, correct it if necessary, and then update it. The data processing medium is the ideal format for this type of constantly evolving data. The second goal is to statistically process this mass of data.

2 Currently president of the CIPL, and teacher-researcher and lecturer in Belgian Francophone poetry. Björn-Olav Dozo has held the position of CIPL director since September 2016 
La base reprend, à l'heure actuelle, toutes les données prosopographiques disponibles dans les différents travaux existants, tels la Biographie nationale (Thiry, puis Bruylants et Christophe puis Bruylants [dir.] 1866-1986), la Nouvelle Biographie nationale (1988), la Bibliographie des écrivains francophones belges (Brucher puis Detemmerman [dir.] 1958-1988) ou le Dictionnaire des œuvres (Nachtergaele \& Trousson 1988 ; Berg \& Frickx 1988 ; De Grève, d'Heur, Pouilliart 1989 ; Frickx R. et alii 1994). De nombreuses monographies sur la littérature belge ont été dépouillées systématiquement, ainsi que des annuaires professionnels (Mayeur 2010) ${ }^{3}$, des listes de membres, des signataires de manifestes et d'autres textes collectifs. Des registres de naissance, de décès et de résidence ont fait l'objet d'enquêtes de première main, à Bruxelles et à Liège principalement, mais aussi ponctuellement dans d'autres villes de Belgique. Ces données sont structurées et mises en relation de manière raisonnée. La base reprend des données factuelles, non analysées et le moins possible formatées, c'est-à-dire que la saisie de ces données est divisée en deux temps : une première saisie conforme à la source, puis une deuxième, complémentaire, à visée analytique.

La constitution des bases de données s'appuie-t-elle sur un ancrage théorique et/ou disciplinaire précis?

Lorsque l'on parle de bases de données en lettres, on pense souvent aux grands corpus littéraires numérisés, du type Frantext ou, pour la Belgique, "Beltext ». Ces bases de données sont surtout mobilisées par les linguistes. L'histoire de la littérature en

3 [En ligne] http://textyles.revues.org/113 [consulté le 12 février 2018].
The database currently groups together all prosopographical data available in various existing works, such as the Biographie nationale (Thiry, then Bruylants and Christophe then Bruylants [eds.] 1866-1986) the Nouvelle Biographie nationale (1988), the Bibliographie des écrivains francophones belges (Brucher then Detemmerman [eds.] 1958-1988), and the Dictionnaire des œuvres (Nachtergaele \& Trousson 1988; Berg \& Frickx 1988; De Grève, d'Heur, Pouilliart 1989; Frickx R. et alii 1994). Many monographs about Belgian literature were systematically examined, as well as professional directories (Mayeur 2010), ${ }^{3}$ lists of members, and signatories of manifestos and of other collective texts. Birth, death, and place of residence registers were the object of first-hand inquiries, primarily in Brussels and Liège, but also from time to time in other Belgian cities. This data is structured and linked logically. The database collects factual data, unanalysed and formatted as little as possible, which is to say that the data intake is divided into two steps: a primary intake conforms to the source, then a second, complementary intake for analytical purposes.

\section{Is the design of the database supported by a specific theory and/or discipline?}

When we speak about databases in literature, we often think of major digital literary corpora such as "Frantext" or, for Belgium, "Beltext." These databases are set up mostly by linguists. The history of literature makes little use of them, even though things have evolved, notably with the perspectives opened up by the work of Franco Moretti (2005). Alongside these textual databases, the history of the literary and sociological life of authors has developed

3 [On line] http://textyles.revues.org/113 [accessed on 12 february 2018]. 
fait peu d'usage, même si les choses évoluent, notamment avec les perspectives ouvertes par les travaux de Franco Moretti (2008).

À côté de ces bases de données textuelles, l'histoire de la vie littéraire et la sociologie des écrivains a développé ses propres bases de données. La base de données du CIEL en constitue un exemple pionnier en la matière.

\section{Quels logiciels avez-vous utilisés pour bâtir l'infrastructure des bases de données, et, le cas échéant, pour leur exploitation statistique?}

Le cœur de la base de données a été développé sous Microsoft Access, pour des raisons de facilité de déploiement et de possibilité de rapides amendements lors des premières phases du développement (allers-retours entre les chercheurs qui dépouillaient les sources et l'informaticien, avec un chercheur jouant le rôle d'interface entre les deux métiers). La montée en charge s'est bien déroulée : sur le réseau local de l'université, MS Access permettait l'encodage simultané au sein de la base de données de jusqu'à vingt personnes en même temps, via les formulaires spécifiques.

En revanche, quand il a fallu saisir de l'information à distance, via Internet, lors de dépouillement à plusieurs en bibliothèque par exemple, différentes pages web en ASP.NET ont dû être développées. Grâce à elles, il est possible de modifier la base de données à distance à plusieurs, sans souci de synchronisation de copies différentes. La seule nécessité était de disposer d'une connexion internet, ce qui est un enjeu mineur aujourd'hui.

Enfin, pour la base de données publique, nous avons choisi de transformer la base de données MS Access en une infrastructure plus robuste pour supporter de plus nombreuses connexions multiples, en utilisant Microsoft SQL, toujours avec une couche web its own databases. The CIEL database constitutes a pioneering example of this.

\section{Which software programs were used to build the database infrastructure and, as the case may be, to treat the data statistically?}

The core of the database was developed using Microsoft Access, because it is easy to use, and because it is easy to make changes quickly during the preliminary development phases (i.e. going back and forth from the researchers who were going through the sources, to the computer technician, with a researcher playing the role of interface between the two). The ramp-up went well: on the university's local network, MS Access allowed simultaneous encoding within the database by up to twenty people at the same time, via specific forms.

However, when it was necessary to capture information from a distance via the internet - with several people going through sources at the library, for example - different web pages in ASP. NET had to be developed. Using these, it is possible for several people to modify the database from a distance, without concern for the synchronization of different copies. The only requirement is access to an internet connection, which is a minor factor today.

Finally, for the public database, we chose to transform the MS Access database into a more robust infrastructure in order to support multiple connections using Microsoft SQL, still with an ASP. 
ASP.NET ${ }^{4}$. Chaque nuit, la base de données MS Access (celle qui est modifiable en ligne) est d'une part sauvegardée et d'autre part dupliquée en MS SQL et écrase la version antérieure de la base de données publique (uniquement consultable en ligne).

Concernant l'exploitation statistique de la base de données, étant donné que nous travaillions dans l'environnement de Microsoft, nous avons eu recours, pour les analyses factorielles, à un plugin payant pour Excel, XL-Stat, qui offre une interface assez claire et accessible. Pour l'analyse structurale de réseaux sociaux, nous avons utilisé le logiciel standard en 2005, Ucinet, et son pendant graphique, Netdraw. En revenant sur ces logiciels, vu de 2017, et en utilisant maintenant Gephi par exemple, on ne peut que constater que le temps passe..

\section{Pouvez-vous donner en exemple un ou deux résultats scientifiques (attendu ou surprenant) obtenus à l'aide des bases de données ?}

L'un des acquis majeurs de la base de données du CIEL fut la démonstration de l'importance des animateurs de la vie littéraire en Belgique francophone. Si l'intuition des chercheurs porteurs du projet au départ allait dans le sens d'une « institution littéraire faible » (Aron \& Denis 2006), faisant une large place aux relations interpersonnelles dans la structuration du sous-champ littéraire belge francophone, la collecte systématique des données et leur mise en série permit de confirmer et d'expliciter cette intuition (Dozo 2011).

4 À refaire, une solution à partir de logiciels libres serait sans doute envisagée, mais les compétences des informaticiens étaient du côté des solutions logicielles de Microsoft.
NET web layer. ${ }^{4}$ Every night, the MS Access database (the version that is modifiable online) is first backed up and then duplicated in MS SQL, while the previous version of the public database (accessible only online) is overwritten.

Regarding the statistical exploitation of the database, given that we were working in the Microsoft environment, we chose, for factor analyses, a payable plug-in for Excel, XL-Stat, which offers an interface that is relatively clear and accessible. For the social networks structural analysis, we used Ucinet, the standard software program in 2005, and its graphical counterpart, Netdraw. Looking back on these software programs from a 2017 perspective, now using Gephi, for example, it is clear how much things have moved on.

\section{Could you offer one or two examples of scientific (whether consensual or surprising) results obtained with the help of the database?}

One of the major assets of the CIEL databases is the demonstration of the importance of "literary life animators" (see further down) in Francophone Belgium. The project leaders' intuition at the start tended towards a "weak literary institution" (Aron \& Denis 2006); for this reason, they gave a lot of importance, in the structure of the Belgian Francophone literary sub-field, to interpersonal relationships: the systematic collection and serialization of the data helped confirm and elucidate this intuition (Dozo 2011).

4 If we were to do it again, an open-source software solution would doubtless be considered, but the competencies of the programmers lay at the time with Microsoft digital solutions. 
À partir de la reconstitution (reconstruction) du réseau des relations individuelles des écrivains, nous avons repéré les cas intéressants en utilisant des indicateurs de centralité pour chaque individu. Certains écrivains ont ainsi des indices de centralité très élevés, ce qui permet de les distinguer des autres. Parmi les écrivains qui se distinguent, certains étaient attendus, étant donné la connaissance préalable que l'on a de leur rôle au sein de l'histoire littéraire (Franz Hellens, Albert Mockel, etc.) ; d'autres l'étaient beaucoup moins, comme Gaston Pulings, Pierre Fontaine ou encore Paul Werrie. Ces écrivains au grand nombre de relations, ou à la position structurale relationnelle remarquable (voir le concept de trous structuraux), nous

les avons nommés les animateurs de la vie littéraire (Dozo 2014).

Un autre usage de la base de données fut le portrait statistique de l'espace social et littéraire en Belgique francophone. Au moyen d'analyses factorielles, nous avons pu situer les générations littéraires actives et leurs traits significatifs (Dozo 2009), ou nous concentrer sur une profession et interroger son articulation avec la pratique de la littérature (Dozo 2010). On peut aussi citer la géolocalisation des résidences des écrivains bruxellois à différentes époques de

développement de la ville (Debroux, Dozo, Vanderpelen 2015).

\section{Qu'envisagez-vous pour la pérennité et l'accessibilité de ces données numérisées ?}

La base de données est disponible dans une version publique à l'adresse ciel.philo.ulg.ac.be. Elle est accessible gratuitement sur inscription et offre une consultation par fiche " auteur ", « œuvre » et « revue ». La section " revues » offre d'importantes ressources numérisées, fruit du deuxième projet ARC CIEL porté par l'Université libre de Bruxelles, sous la direction de Paul Aron. Quelques requêtes croisées sont également disponibles (événements sur une année,

lieux, etc.).
With the help of a reconstitution (construction) of the network of authors' individual relationships, we pinpointed interesting cases using indicators of centrality for each individual. Certain authors have very high indicators of centrality which help distinguish them from others. Among the authors who stand out, some were expected given the previous knowledge of their role within literary history (Franz Hellens, Albert Mockel, etc.). Others, such as Gaston Pulings, Pierre Fontaine, and Paul Werrie were much less so. We named these writers with large tallies of relationships, or with a significant structural relational position (see the concept of structural gaps), "literary life animators" (Dozo 2014).

Another use of the database was the statistical portrait of the social and literary space in Francophone Belgium. By way of factor analyses, we were able to situate active literary generations and their significant characteristics (Dozo 2009), or focus on one profession and study its links to literary practice (Dozo 2010). We could also mention the geolocalization of authors' residences in Brussels during different periodes of the city's development (Debroux, Dozo, Vanderpelen 2015).

\section{What plans do you have with regard to the perpetuity and accessibility of this database?}

A public version of the database is available at ciel.philo.ulg.ac.be. Subscription is free of charge and offers the possibility to search by "author," "work," or "journal." The "journals" section offers many digitized resources - the fruits of the second project, ARC CIEL, supported by the Université libre of Brussels under the direction of Paul Aron. Some cross-referenced inquiries are also available (events over one year, places, etc.)

Université de Liège - Centre informatique de philosophie et lettres 


\section{Références bibliographiques}

Aron Paul \& Denis Benoît (2006). « Réseaux et institution faible ». In MARneffe (DE) Daphné \& Benoît Denis (éd.). Les Réseaux littéraires. Bruxelles, Le Cri/CIEL/ULB/ULg : 7-18.

Aron Paul, Denis Benoît, KLInKenBerg Jean-Marie (2006). « Littérature belge et recherche collective ». Textyles, 29 : 90-97. [En ligne] http:// textyles.revues.org/455 [consulté le 15 janvier 2018].

BERG Christian \& FRICKX Robert (dir.) (1988). Lettres françaises de Belgique. Dictionnaire des œuvres. II. La poésie. Louvain-la-Neuve, Duculot.

BruCher Roger puis Detemmerman Jacques (dir.) (1958-1988). Bibliographie des écrivains français de Belgique. Bruxelles, Palais des Académies, 5 vol.

Debroux Tatiana, Dozo Björn-Olav, VanderPelen Cécile (2015). « Les lieux d'habitation des écrivains belges francophones à Bruxelles (19301960). Premiers jalons pour une histoire sociogéographique ». Textyles, $46: 139-157$.

De Grève Marcel, D'Heur Jean-Marie, Pouilliart Raymond (dir.) (1989). Lettres françaises de Belgique. Dictionnaire des œuvres. III. Le Théâtre et l'Essai. Louvain-la-Neuve, Duculot.

Dozo Björn-Olav (2009). «Sociabilités et réseaux littéraires au sein du sous-champ belge francophone de l'entre-deux-guerres ». Histoire \& Mesure, $\mathrm{XXIV(1)} \mathrm{:} \mathrm{43-72.}$

Dozo Björn-Olav (2010). «Portrait statistique de l'écrivain journaliste en Belgique francophone entre 1920 et $1960 »$. Textyles, $39:$ 123-146.

Dozo Björn-Olav (2011). Mesures de l'écrivain. Profil socio-littéraire et capital relationnel dans l'entre-deux-guerres en Belgique francophone. Liège, Presses Universitaires de Liège - Sciences humaines.

\section{References}

Aron Paul \& DenIs Benoît (2006). "Réseaux et institution faible." In MARneffe (DE) Daphné \& Benoît Denis (eds.). Les Réseaux littéraires. Brussels, Le Cri/CIEL/ULB/ULg: 7-18.

Aron Paul, Denis Benoît, KLINKenBerg Jean-Marie (2006). "Littérature belge et recherche collective." Textyles, 29: 90-97. [On line] http://textyles. revues.org/455 [accessed on 15 january 2018].

BERG Christian \& FrICKX Robert (eds.) (1988). Lettres françaises de Belgique. Dictionnaire des œuvres. II. La poésie. Leuven, Duculot

Brucher Roger then Detemmerman Jacques (eds.) (1958-1988) Bibliographie des écrivains français de Belgique. Brussels, Palais des Académies, 5 vol.

Debroux Tatiana, Dozo Björn-Olav, Vanderpelen Cécile (2015). “Les lieux d'habitation des écrivains belges francophones à Bruxelles (1930-1960). Premiers jalons pour une histoire sociogéographique." Textyles, 46: 139157.

De Grève Marcel, D’Heur Jean-Marie, Pouilliart Raymond (eds.) (1989). Lettres françaises de Belgique. Dictionnaire des œuvres. III. Le Théâtre et I'Essai. Leuven, Duculot.

Dozo Björn-Olav (2009). "Sociabilités et réseaux littéraires au sein du sous-champ belge francophone de l'entre-deux-guerres." Histoire \& Mesure, $\mathrm{XXIV(1):} \mathrm{43-72}$

Dozo Björn-Olav (2010). "Portrait statistique de l'écrivain journaliste en Belgique francophone entre 1920 et 1960." Textyles, 39: 123-146.

Dozo Björn-Olav (2011). Mesures de l'écrivain. Profil socio-littéraire et capital relationnel dans l'entre-deux-guerres en Belgique francophone. Liège, Presses Universitaires de Liège - Sciences humaines. 
Dozo Björn-Olav (2014). « Les animateurs de la vie littéraire en Belgique francophone : de leur rôle interne à leur position de médiateur transnational ». In BLANCHARD Nelly \& THOMAS Mannaig (dir.). Des littératures périphériques. Rennes, Presses Universitaires de Rennes : 251-263.

FRICKX Robert et alii (1994). Lettres françaises de Belgique. Dictionnaire des œuvres. IV. 1981-1990. Louvain-la-Neuve, Duculot.

MAYEUR Ingrid (2010). " Les écrivains-journalistes (1920-1960) 》. Textyles, 39 : 145-168. [En ligne] http://textyles.revues.org/113 [consulté le 12 février 2018].

MORETTI Franco (2008). Graphes, cartes et arbres. Modèles abstraits pour une autre histoire de la littérature. Traduit de l'anglais par Étienne Dobenesque. Paris, Les Prairies ordinaires.

NACHTERgaEle Vic \& Trousson Raymond (dir.) (1988). Lettres françaises de Belgique. Dictionnaire des œuvres. I. Le roman. Louvain-la-Neuve, Duculot.

Nouvelle biographie nationale (1988-). Bruxelles, Académie royale des sciences, des lettres et des beaux-arts de Belgique, 6 vol.

ThiRY H., puis Bruylants E. et Christophe Ch. puis Bruylants E. (dir.) (1866-1986). Biographie nationale publiée par l'Académie royale des sciences, des lettres et des beaux-arts de Belgique. Bruxelles, H. Thiry/ van Buggenhoudt, 44 vol.
Dozo Björn-Olav (2014). "Les animateurs de la vie littéraire en Belgique francophone: de leur rôle interne à leur position de médiateur transnational." In BLANCHARD Nelly \& ThOMAS Mannaig (eds.). Des littératures périphériques. Rennes, Presses Universitaires de Rennes: 251-263.

FrICKX Robert et alii (1994). Lettres françaises de Belgique. Dictionnaire des œuvres. IV. 1981-1990. Leuven, Duculot.

MAYEUR Ingrid (2010). "Les écrivains-journalistes (1920-1960)." Textyles, 39: 145-168. [On line]: http://textyles.revues.org/113 [accessed on 12 february 2018].

MoRETtI Franco (2005). Graphs, Maps, Trees: Abstract Models for a Literary History. New York, Verso.

Nachtergaele Vic \& Trousson Raymond (eds.) (1988). Lettres françaises de Belgique. Dictionnaire des œuvres. I. Le roman. Leuven, Duculot.

NouVelle biographie nationale (1988-). Brussels, Académie royale des sciences, des lettres et des beaux-arts de Belgique, 6 vol.

ThiRY H., then Bruylants E. and Christophe Ch. then BruYLANTS E. (eds.) (1866-1986). Biographie nationale publiée par l'Académie royale des sciences, des lettres et des beaux-arts de Belgique. Brussels, H. Thiry/ van Buggenhoudt, 44 vol. 